\title{
The anti-integrity activity of eugenol on inflammatory markers of chronic atherosclerosis
}

Venkadeswaran Karuppasamy ( $\nabla$ venkadeswaran@psr.edu.in )

P.S.R. Engineering College

Suresh Kumar Sekar

P.S.R. Engineering College

Subramanian Kandhasamy

P.S.R. Engineering College

Rajeswari Ramasamy

P.S.R. Engineering College

Venkatesh Srinivasan

P.S.R. Engineering College

Varalakshmi Varatharajan

P.S.R. Engineering College

\section{Suganya Ramar}

P.S.R. Engineering College

Shalini Kannan

P.S.R. Engineering College

\section{Research Article}

Keywords: Atherosclerosis, Hypercholesterolemia, Oxidative stress, Antioxidant potential Eugenol, Inflammatory markers

Posted Date: June 10th, 2022

DOl: https://doi.org/10.21203/rs.3.rs-1068261/v3

License: (c) (i) This work is licensed under a Creative Commons Attribution 4.0 International License.

Read Full License 


\section{Abstract}

The putative anti-atherogenic, anti-oxidative, and anti-inflammatory potential of atherogenic diet-fed, eugenol-treated Wistar rats were studied. The levels of hematological parameters (ESR, WBC, and platelet count); the mean levels of nitric oxide (NO), and C-reactive protein (CRP) were investigated in serum samples. The mean ESR, platelet, and total WBC counts were all significantly higher in atherogenic dietfed (Group II) rat when compared with normal (Group I), whereas the mean ESR, platelet, and total WBC counts were significantly lower in atherogenic diet-fed followed by eugenol treatment (Group III). The mean hepatic tissue mRNA transcript level of the gene responsible for CRP, iNOS, TNF-a, IL-1 $\beta$, and NF-KB and expression of their protein levels were determined in liver tissue samples were found to be significantly higher in the atherogenic diet-fed followed saline treatment (Group II) rats than the normal fed (Group I) rats. However, in hepatic tissue samples from an atherogenic diet-fed followed by eugenol treated rats, the mean mRNA the transcript level of the gene encoding CRP, iNOS, TNF-a, IL-1 $\beta$, NF-KB and their mean concentration of the protein translation were significantly lower than the values in Group II rat's hepatic tissue, approaching near-normal levels. These results are exhibited anti-atherogenic potential in hypercholesterolemic Wistar rats due to their hypocholesterolemic, antioxidant, and anti-inflammatory effects.

\section{Introduction}

Atherosclerosis is characterized by the development of vascular lesions or plaques in blood vessels following an inflammatory/oxidant response to endothelial damage (Verma et al., 2002; Libby et al., 2010). The first obvious alteration in this disorder is enhanced constriction and reduced dilatation of the vascular endothelium, as well as changes in the mediators of thrombosis. At all stages of atherosclerosis, macrophages are the principal cell type involved (Bjorkerud and Bjorkerud, 1996); these eventually become lipid-laden "foam cells" (Shashkin et al., 2005) by a regulated balance between the uptake of modified low-density lipoprotein (LDL) and efflux of cholesterol and other lipids (Linton and Fazio, 2003).

The inflammatory process has been implicated in the vulnerability of the plaque to rupture. Circulating levels of several inflammatory markers have been found to rise in individuals at risk for atherosclerotic events. In particular, the elevation of plasma C-reactive protein (CRP), a non-specific acute-phase reactant that is easily and reliably measured, has strong predictive power for cardiovascular events (Pepys and Hirschfield, 2003; Black et al., 2004). CRP co-localizes with monocytes, monocyte-derived macrophages, and lipoproteins in the vascular intima (Torzewski et al., 1998; Zwaka et al., 2001); this localization makes a direct contribution to the atherosclerotic process. CRP production level is determined by hepatocytes with the influence of interleukin (IL)-6, IL-1 $\beta$, and tumor necrosis factor-alpha (TNF-a) (Castell et al., 1990). Cytokines activate the classic complement cascade followed by mediates then phagocytosis, by the way, it regulates inflammation. Ridker et al., (1998) and Biasucci et al., (1999) stated that CRP also has a predictive value in the chronic phase after myocardial infarction and act as a marker of inflammation also an active participant at all stages of atherogenesis (Pasceri et al., 2001; Di Napoli et al., 2005; Verma et al., 2005; Colak et al., 2012). 
Nitric oxide is a physiological messenger molecule involved in the pathophysiology of inflammatory disorders. In an animal system, NO is produced with the support of nitric oxide synthase (NOS), through the oxidation of L-arginine. Induced nitric oxide synthase (iNOS) is an isoform that mediates the inflammatory processes. Sam way non-proper regulations of iNOS cause atherosclerosis (Popa et al.,

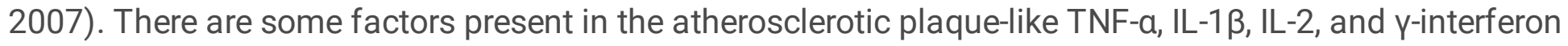
are inducing iNOS expression in vascular smooth muscle cells. Induced iNOS produces large quantities of NO, which may lead to cellular damage, inflammation, apoptosis, and peroxynitrite (ONOO-) formation. Further activated iNOS is causing inflammation and oxidative stress (Nathan, 1994).

The transcription factor NF-kB is involved in the regulation of inflammation, apoptosis, and cell proliferation. A range of stimuli which are including reactive oxygen species (ROS), mitogens, and bacteria act as activators of NF-KB (Brigelius-Flohé, 2006; Gilmore, 2006). Activation of NF-KB can mediate the induction of more than 160 genes have a vital role in atherogenesis (Collins and Cybulsky, 2001). NF-KB is found in endothelial cells, smooth muscle cells, and macrophages of atherosclerotic plaques (Libby, 2012). The IKB kinase (IKK) complex is inducing NF-KB activation. Upon stimulation, the IKK complex phosphorylates IKB, inducing its ubiquitination and subsequent degradation. NF-KB is then free to translocate to the nucleus, where it facilitates the transcription of many genes, including proinflammatory cytokines, chemokines, and antiapoptotic factors (Karin and Ben-Neriah, 2000). These findings suggest that there is a link between antioxidant and anti-inflammatory responses in the regulation of cell proliferation. Hence, various drugs with antioxidative properties are used to treat human inflammatory diseases, including atherosclerosis and diabetes mellitus by designed to inhibit NF-KB activation (Tak and Firestein, 2001).

Eugenol (4-allyl-1-hydroxy-2- methoxybenzene), one of the active constituents of Piper betle is widely used as a natural food flavoring agent in food products and cosmetics. Eugenol is known to possess antioxidant and anti-inflammatory activities (Fujisawa et al., 2000; Li et al., 2006); it has been reported to restore tissue glutathione levels (Parasakthy et al., 1996) in an animal study and to reduce the severity of hepatic injury caused by iron overload (Gruenwald et al., 2004). Ou et al. (2006) opined that eugenol can prevent functional disorders of endothelial cells (resulting from oxidized-LDL) by increasing antioxidant activity to inhibit the generation of active oxygen species. Eugenol has been found to prevent reduced antioxidant activities in Wistar rats fed an atherogenic diet (Venkadeswaran et al., 2016). Hence, in the present chapter, experiments are described that sought to evaluate the role of inflammatory markers in an experimental animal model of (chronic) atherosclerosis, where diseased animals were treated with saline or eugenol. The erythrocyte sedimentation rate (ESR), white blood cell (WBC), and platelet counts and percentages of different leukocytes in whole blood samples, as well as hepatic tissue levels of mRNA transcripts of genes encoding known inflammatory markers, such as CRP, iNOS, NF-kB, TNF-a, and IL-1 $\beta$ and hepatic tissue concentrations of inflammatory marker proteins (CRP, iNOS, NF-kB, and IkB), were determined. In addition, serum levels of CRP and hepatic tissue concentrations of NO were measured in the experimental animals. 


\section{Materials And Methods}

\subsection{Experimental design}

Animals were maintained as per national guidelines and protocols approved by the Institutional Animal Ethical Committee (BDU/ IAEC/2014/OE/07/Dt.18.03.2014). Male albino rats of the Wistar strain weighed in the range of 150-200 g were used in this study. These animals were housed in clean polypropylene cages under controlled temperature room temperature with equal light and dark cycle; during the growing period, rats were free to access water and food. The experimental animals were fed twice a day with commercial feed obtained from Sai Durga Feeds and Foods P. Ltd., Bengaluru, India. Male albino Wistar rats were divided into three main groups, each group comprising five rats. Group I animals was fed with normal feed, Group II animals were fed with an atherogenic diet was prepared by mixing equal quantities of a commercial feed with an atherogenic diet containing $5 \%$ cholesterol, $20 \%$ sucrose, $20 \%$ hydrogenated vegetable oil, $2 \%$ sodium cholate, $20 \%$ lactose, $0.4 \%$ choline chloride and $0.15 \%$ thiouracil. This prepared feed was fed for the first 30 days and then fed with a normal diet. Group III animal was fed with an atherogenic diet for 30 days afterward fed with normal diet and 31st day onwards orally fed eugenol (Sigma Chemical) dissolved in $0.5 \%$ peanut oil ( $5 \mathrm{mg} / \mathrm{kg}$ body weight/day) daily for 15 days.

\subsection{Atherosclerosis analysis}

At the end of the experimental period, all the animals were sacrificed by cervical dislocation. Immediately post-mortem, blood samples were collected from each animal and $1.5 \mathrm{ml}$ of blood were added to $0.5 \mathrm{ml}$ of $10 \%$ EDTA solution, mixed well, and then used to measure hematological parameters. The remaining volume of blood was allowed to clot and serum was separated from this for analysis of other markers of inflammation. The hepatic tissues were excised and stored at $-80^{\circ} \mathrm{C}$ until analysis.

\subsection{Measurement of hematological parameters and serum CRP levels}

The ESR was measured by using the Westergren method (Gilmour and Sykes, 1951). Total WBC and platelet counts were performed on the EDTA blended blood samples using an automated blood cell counter. Smears were also made from the blood samples, stained appropriately and differential WBC percentages were determined by desert microscopic examination. CRP in each serum sample was determined by an immuno-turbidimetric method using a standard assay kit (C-Reactive Protein test kit, Diasys Diagnostics, Holzheim, Germany). All the generated data were statistically analyzed using SPSS software (Version 16.0).

\subsection{Preparation of hepatic tissue samples for analysis}

Hepatic tissue (100mg/ml buffer) was homogenized with $50 \mathrm{mM}$ phosphate buffer ( $\mathrm{pH} 7.0)$; the homogenate was then centrifuged at $12,000 \times \mathrm{g}$ for 15 mins and the supernatant was thus obtained was used for further analysis. The protein concentration of each fraction was determined by the Bradford 
method (Bradford, 1976), using crystalline bovine serum albumin (heat shock fraction, $\geq 98 \%$ purity, units $=40 \mathrm{mg} / \mathrm{mL} \mathrm{H}_{2} \mathrm{O}$ [Sigma Chemical]) as a standard. The absorbance was read at $595 \mathrm{~nm}$ using a UV-visible spectrophotometer.

\subsection{Reverse transcription of CRP, iNOS, NF-kB, TNF- $a$, and IL-13 mRNAs}

\subsubsection{RNA extraction}

Total RNA was extracted from the freshly isolated hepatic tissue of the experimental rats using TRIzol reagent (Sigma-Aldrich). Briefly, the fresh hepatic tissue $(100 \mathrm{mg} / \mathrm{ml})$ was homogenized in TRIzol reagent and the homogenate was transferred immediately to a microcentrifuge tube and kept at $4^{\circ} \mathrm{C}$ for 5 min to permit the complete dissociation of nucleoprotein complexes. Then, $0.2 \mathrm{ml}$ chloroform was added to the homogenate, followed by vigorous vortexing for $15 \mathrm{sec}$ and incubation at $4^{\circ} \mathrm{C}$ for $10 \mathrm{~min}$. After incubation, the mixture was centrifuged at $12,000 \times \mathrm{g}$ for $15 \mathrm{~min}$ at $4^{\circ} \mathrm{C}$. The upper aqueous phase (600 $\mu l)$ was carefully transferred to a fresh microcentrifuge tube and an equal volume of isopropanol (100\%) was added, followed by thorough vortexing; the solution was then incubated at $4^{\circ} \mathrm{C}$ for $10 \mathrm{~min}$. Next, the incubated mixture was centrifuged at $12,000 \times \mathrm{g}$ for $10 \mathrm{~min}$; the supernatant was removed and the pellet was washed twice with $75 \%$ ethanol by vortexing and subsequently centrifuged at 7,500 $\times \mathrm{g}$ for $5 \mathrm{~min}$ $\left(4^{\circ} \mathrm{C}\right)$. After centrifugation, the ethanol was removed carefully and the pelleted RNA was allowed to dry for $10 \mathrm{~min}$. The pelleted RNA was resuspended in $50 \mu \mathrm{l}$ of RNase-free water; the concentration and purity of total RNA were determined by absorbance at $260 / 280 \mathrm{~nm}$ in a UV-spectrophotometer and the integrity of the total RNA was checked via agarose gel electrophoresis by assessing $18 \mathrm{~S}$ and $28 \mathrm{~S}$ band intensities.

\subsubsection{Reverse transcription-polymerase chain reaction (RT- PCR)}

RT-PCR was performed using a one-step RT-PCR kit (Qiagen, Hilden, Germany) with gene-specific primers (EUROFINS, Bengaluru, India) for CRP, iNOS, NF-KB, TNF-a, IL-1 $\beta$, and $\beta$-actin (Table 1). The molecular size of the amplified products (CRP, iNOS, NF-KB, TNF-a, IL-1 $\beta$, and $\beta$-actin) were determined by comparison with molecular weight markers (100 bp DNA ladder, Genei, Bengaluru, India) run in parallel with the RT-PCR products. The ethidium bromide-stained gel was subjected to densitometric scanning and the band intensity of the cDNA fragment of the genes was normalized against the band intensity of the cDNA fragment of the internal control ( $\beta$-actin) gene, using Quantity One Software (Bio-Rad, Hercules, CA, USA). 
Table 1

Primer sequences and expected product sizes of the genes amplified in hepatic tissue samples from Wistar rats

\begin{tabular}{|c|c|c|c|}
\hline $\begin{array}{l}\text { Gene } \\
\text { studied }\end{array}$ & Primer & Primer sequence & $\begin{array}{l}\text { Amplicon } \\
\text { size (bp) }\end{array}$ \\
\hline \multirow[t]{2}{*}{ CRP } & Forward & $\begin{array}{l}\text { 5'- AGC CTC TCT CAT GCT TTT GG } \\
-3^{\prime}\end{array}$ & \multirow[t]{2}{*}{280} \\
\hline & Reverse & $\begin{array}{l}\text { 5'- TGT CTC TTG GTG GCA TACGA - } \\
3^{\prime}\end{array}$ & \\
\hline \multirow[t]{2}{*}{ iNOS } & Forward & $\begin{array}{l}\text { 5'- CCA ACC TGC AGG TCT TCG ATG } \\
-3^{\prime}\end{array}$ & \multirow[t]{2}{*}{258} \\
\hline & Reverse & $\begin{array}{l}\text { 5'- GTC GAT GCA CAA CTG GGT } \\
\text { GAA-3' }\end{array}$ & \\
\hline \multirow[t]{2}{*}{ IL-1 $\beta$} & Forward & $\begin{array}{l}5 '-\text { GCC TCG TGC TGT CTG ACC CA } \\
-3^{\prime}\end{array}$ & \multirow[t]{2}{*}{191} \\
\hline & Reverse & $\begin{array}{l}\text { 5'- CAG GGT GGG TGT GCC GTC TT } \\
-3^{\prime}\end{array}$ & \\
\hline \multirow[t]{3}{*}{ NF-kB } & Forward & $\begin{array}{l}\text { 5'- ACT CGC CAC CCG GCT TCA GAA } \\
\text { TGG CAG - } 3^{\prime}\end{array}$ & \multirow[t]{3}{*}{151} \\
\hline & Reverse & $\begin{array}{l}\text { 5'- AGG TAT GGG CCA TCT GCT GTT } \\
\text { GGC }\end{array}$ & \\
\hline & & AGT GC-3' & \\
\hline \multirow[t]{2}{*}{ TNF a } & Forward & $\begin{array}{l}\text { 5'- GGG GGC CAC CAC GCT CTT CT } \\
-3^{\prime}\end{array}$ & \multirow[t]{2}{*}{336} \\
\hline & Reverse & $\begin{array}{l}\text { 5'- AGG AGC ACG TAG TCG GGG CA } \\
-3^{\prime}\end{array}$ & \\
\hline \multirow[t]{2}{*}{$\begin{array}{l}\text { ß-actin (Served as an } \\
\text { "housekeeping" gene) }\end{array}$} & Forward & $\begin{array}{l}\text { 5'- ATC GCT GAC AGG ATG CAG AAG } \\
-3^{\prime}\end{array}$ & \multirow[t]{2}{*}{108} \\
\hline & Reverse & $\begin{array}{l}\text { 5'- AGA GCC ACC AAT CCA CAC AGA } \\
-3^{\prime}\end{array}$ & \\
\hline
\end{tabular}

\section{Abbreviations}

$\mathrm{CRP}=$ C-reactive protein

iNOS = inducible nitric oxide synthase 
IL $-1 \beta=$ interleukin-1 beta

$\mathrm{NF}-\mathrm{kB}=$ nuclear factor-kappa $\mathrm{B}$

$\mathrm{TNFa}=$ tumor necrosis factor- $\mathrm{a}$

\subsection{Immunoblot analysis}

Immunoblot analyses were performed to determine the relative concentrations of CRP, iNOS, NF-KB, and IKB in samples from the various groups of rats. Proteins subjected to SDS-PAGE were electrophoretically transferred to a polyvinylidene fluoride (PVDF) membrane using a semi-dry blotting apparatus (Bio-Rad, Hercules, CA, USA). Blotting was done at $24 \mathrm{~V}$ for $1 \mathrm{~h}$. Blotted membranes were stained by Ponceau $\mathrm{S}$ solution to check for the efficiency of transfer; subsequently, blocking was done with $5 \%$ non-fat dry milk in Tris-buffered saline ( $\mathrm{pH} 7.5)$ with $0.1 \%(\mathrm{v} / \mathrm{v})$ Tween 20 for $2 \mathrm{~h}$. Antibodies against CRP (1:400 dilution) and iNOS (1:1000 dilution) [Sigma Chemical], as well as antibodies to NF-KB (1:200 dilution) and IKB(1:400 dilution) [Santa Cruz Biotechnology, USA], were used. Immuno-reactivity was visualized with alkaline phosphatase-conjugated to anti-mouse IgG secondary antibodies and 5-Bromo 4-chloro 3-indolyl phosphate/nitroblue tetrazolium chloride (Genei, Bengaluru, India). To detect even minimal differences in the intensity of the bands, densitometry was performed on scanned images of the membrane; Quantity One software (Bio-Rad, USA) was used to analyze the scanned images.

\subsection{Measurement of nitric oxide levels in hepatic tissue}

NO levels were indirectly determined by measuring nitrite levels using a colorimetric method based on the Griess reaction (Green et al., 1982). In brief, $500 \mu$ l of test sample/standard were mixed with $500 \mu \mathrm{l}$ of freshly prepared Griess reagent (detects the presence of nitrite ion in a solution). The mixtures were kept in the dark for $10 \mathrm{~min}$ at room temperature. The optical density was measured at $540 \mathrm{~nm}$ in a spectrophotometer in comparison with a standard curve of known concentrations of sodium nitrite. The results obtained were expressed as $\mu \mathrm{m} / \mathrm{gm}$ wet tissue. All quantitative data were statistically analyzed using SPSS software (Version 16.0).

\section{Results}

\subsection{Haematological parameters in blood samples 3.1.1 Mean ESR values and mean total WBC and platelet counts}

The mean ESR, platelet count, and total WBC count values in EDTA blended blood samples from atherogenic diet-fed (Group II) rats were found to be significantly $(P<0.05)$ higher than those in control (Group I) rats; the mean values of these three parameters were significantly $(P<0.05)$ lower in rats fed the 
atherogenic diet followed by eugenol treatment (group III) than those rats were fed the atherogenic diet followed by saline oral treatment (group II) (Fig. 1).

\subsubsection{Differential leucocyte profile}

The mean count percentages of neutrophils and monocytes were found to be significantly $(P<0.05)$ higher in blood samples from Group II rats than those in Group I rats, whereas the count values of neutrophils and monocytes in Group III rat samples were significantly $(P<0.05)$ lower than those noted in Group II rat samples. A significantly $(P<0.05)$ lower mean lymphocyte percentage was noted in blood samples from Group II rats than that noted in Group I rats. However, the mean lymphocyte percentage in samples from Group III rats was significantly $(P<0.05)$ higher than that in samples from Group II rats (Fig. 1). No significant differences were noted in the mean eosinophil percentages in blood samples from all three groups of rats; basophils were not detected in blood samples from any of the groups (Table 2).

Table 2

Differential leucocyte percentages in blood samples from Wistar rats

\begin{tabular}{|c|c|c|c|}
\hline $\begin{array}{l}\text { Parameters } \\
\text { tested }^{*} \\
\text { (unit) }\end{array}$ & $\begin{array}{l}\text { Group I } \\
\text { (control } \\
\text { rats) }\end{array}$ & $\begin{array}{l}\text { Group II } \\
\text { (atherogenic diet-fed, saline- } \\
\text { treated rats) }\end{array}$ & $\begin{array}{l}\text { Group III } \\
\text { (atherogenic diet-fed, eugenol- } \\
\text { treated rats) }\end{array}$ \\
\hline $\begin{array}{l}\text { Neutrophil } \\
\text { (\% of total } \\
\text { WBCs) }\end{array}$ & $\begin{array}{l}4.36 \pm \\
0.15\end{array}$ & $8.02 \pm 0.02^{a}$ & $6.71 \pm 0.23^{\mathrm{ab}}$ \\
\hline $\begin{array}{l}\text { Lymphocyte } \\
\text { (\% of total } \\
\text { WBCs) }\end{array}$ & $\begin{array}{l}62.6 \pm \\
13.84\end{array}$ & $83.4 \pm 8.95^{\mathrm{a}}$ & $95.0 \pm 9.05^{\mathrm{ab}}$ \\
\hline $\begin{array}{l}\text { Monocytes } \\
\text { (\% of total } \\
\text { WBCs) }\end{array}$ & $\begin{array}{l}2.26 \pm \\
0.57\end{array}$ & $4.58 \pm 0.29^{a}$ & $3.75 \pm 0.69^{\mathrm{ab}}$ \\
\hline \multicolumn{4}{|c|}{$\begin{array}{l}\text { * Eosinophils accounted for only } 1 \% \text { of total leucocytes in each group while basophils were not } \\
\text { detected in samples from any of the groups }\end{array}$} \\
\hline \multicolumn{4}{|c|}{$\begin{array}{l}\star \star \text { Values represent the mean } \pm \text { SD of observations made on six rats in each group. Statistical } \\
\text { analysis: one-way analysis of variance [ANOVA] with post hoc testing [least significant difference] }\end{array}$} \\
\hline \multicolumn{4}{|c|}{ aStatistically significant difference $(P<0.05)$ when compared with Group I values. } \\
\hline
\end{tabular}

\subsection{CRP levels in serum samples}

The mean level of CRP in serum samples from Group II rats was significantly $(P<0.05)$ higher than that in serum samples from Group I rats, however, the mean serum level of CRP was significantly $(P<0.05)$ 
lower in samples from Group III rats than that noted in Group II rat samples (Table 3).

Table 3

Mean levels of C-reactive protein in serum samples from Wistar rats

\begin{tabular}{|llll|}
\hline $\begin{array}{l}\text { Parameter } \\
\text { tested }\end{array}$ & $\begin{array}{l}\text { Group I } \\
\text { (control } \\
\text { rats) }\end{array}$ & $\begin{array}{l}\text { Group II } \\
\text { (atherogenic diet-fed, saline- } \\
\text { treated rats) }\end{array}$ & $\begin{array}{l}\text { Group III } \\
\text { (atherogenic diet-fed, eugenol- } \\
\text { treated rats) }\end{array}$ \\
\hline $\begin{array}{l}\text { C-reactive } \\
\text { protein }\end{array}$ & $\begin{array}{l}15.44 \pm \\
0.70\end{array}$ & $19.07 \pm 1.26^{\mathrm{a}}$ & $13.27 \pm 0.19^{\mathrm{b}}$ \\
\hline \multicolumn{2}{|l}{ Values represent the mean \pm SD of observations made on six rats in each group. } \\
\hline
\end{tabular}

Units: $\mathrm{mg} / \mathrm{I}$

Statistical analysis: one-way analysis of variance [ANOVA] with post hoc testing [least significant difference]

aStatistically significant difference $(P<0.05)$ when compared with Group I values.

bStatistically significant difference $(P<0.05)$ when compared with Group II values.

\section{3 mRNA transcript levels of CRP, iNOS, NF-kB, TNF- $a$, and IL-1 $\beta$ genes in hepatic tissue of Wistar rats}

The mean mRNA transcript level of CRP in hepatic tissues of Group II (atherogenic diet-fed followed by saline treatment) rats was found to be significantly $(P<0.05)$ higher than that in Group I (normal diet followed by saline treatment) rat hepatic tissue; however, the mean level of mRNA transcripts of CRP in samples from Group III (atherogenic diet-fed followed by eugenol treatment) rats was found to be significantly $(P<0.05)$ lower than that in the hepatic tissue samples from Group II rats (Figs. 2a and $2 b)$. When the mean mRNA transcript levels of iNOS, NF-KB, TNF- $\alpha$ and IL-1 $\beta$ in hepatic tissues were compared between groups (Figures. 3, 4, 5 and 6), the mean levels in Group II rats were found to be significantly $(P<$ 0.05 ) higher than those in Group I (normal) rats. However, the mean levels of mRNA transcripts of iNOS, NF-KB, TNF- $\alpha$ and IL-1 $\beta$ genes in hepatic tissue samples from atherogenic diet-fed followed by eugenol treatment (Group III) rats were significantly $(P<0.05)$ lower than those Group II rats hepatic tissue samples and approached the mean levels noted in hepatic tissue samples from control rats (Figs. 3, 4, 5 $\& 6)$.

\subsection{CRP, iNOS, NF-kB and IkB level in hepatic tissue}

The mean intensities of the Western Blot bands corresponding to the proteins, CRP, iNOS, NF-KB, and IкB, were significantly $(P<0.05)$ higher in hepatic tissue samples from Group II rats than those in hepatic tissue samples from normal control (Group I) rats and were also significantly $(P<0.05)$ higher in hepatic tissue samples from Group III rats (Fig. 7). 


\subsection{NO level in hepatic tissue samples}

The mean level of NO in hepatic tissue samples from atherogenic diet-fed followed by saline treatment rats was significantly $(P<0.05)$ higher than those in samples from control (Group I) rats. The mean NO level in hepatic tissue samples from atherogenic diet-fed, eugenol-treated (Group III) rats was significantly $(P<0.05)$ lower than that in the samples from atherogenic diet-fed, saline-treated (Group II) rats, but still significantly $(P<0.05)$ higher than that noted in hepatic tissue samples from normal control (Group I) rats (Table 4).

Table 4

Mean levels of nitric oxide in hepatic tissue samples from Wistar rats

\begin{tabular}{|llll|}
\hline $\begin{array}{l}\text { Parameters } \\
\text { tested }\end{array}$ & $\begin{array}{l}\text { Group I } \\
\text { (control } \\
\text { rats) }\end{array}$ & $\begin{array}{l}\text { Group II } \\
\text { (atherogenic diet-fed, saline- } \\
\text { treated rats) }\end{array}$ & $\begin{array}{l}\text { Group III } \\
\text { (atherogenic diet-fed, eugenol- } \\
\text { treated rats) }\end{array}$ \\
\hline Nitric oxide & $\begin{array}{l}167.5 \pm \\
18.49\end{array}$ & $387.3 \pm 76.61^{\mathrm{a}}$ & $236.3 \pm 39.95^{\mathrm{b}}$ \\
\hline \multicolumn{2}{|l}{ Values represent the mean \pm SD of observations made on six rats in each group. } \\
\hline
\end{tabular}

Units: $\mu \mathrm{mols} / \mathrm{g}$ tissue.

Statistical analysis: one-way analysis of variance [ANOVA] with post hoc testing [least significant difference]

aStatistically significant difference $(P<0.05)$ when compared with Group I values.

bStatistically significant difference $(P<0.05)$ when compared with Group II values.

\section{Discussion}

Despite the first description of inflammation in coronary atherosclerosis 200 years back, it is only recently that there has been a wide acceptance of the role of inflammation in the pathogenesis of atherosclerosis and destabilization of the coronary artery plaque (Mehta et al., 2007; Silvestre-Roig et al., 2014). Inflammation in the vessel wall is now considered to play an essential role in the initiation, progression, and final steps of atherosclerosis, namely plaque destabilization and eventually plaque rupture (Shrivastava et al., 2015). In consideration of the important role that inflammatory processes play in atherosclerosis, much work has been focused on whether biomarkers of inflammation may help to improve risk stratification and identify patient groups who might benefit from particular treatment strategies (Shrivastava et al., 2015).

Hypercholesterolemia is a major risk factor for systemic atherosclerosis and subsequent cardiovascular disease (Prasad and Kalra, 1993). The indicators of systemic inflammation, such as ESR, platelet count, and total WBC count, are frequently used as markers that appear to be positively correlated with 
cardiovascular disease in humans (Thaulow et al., 1991; Huang et al. 2001). Erikssen et al. (2000) previously reported that the ESR may be a good indicator of coronary heart disease, mortality, and the risk of death from coronary heart disease in a clinical setting. The relationship between the ESR and the risk of coronary heart disease was also assessed in a cohort study by Andresdottir et al. (2003). In the present study, the mean ESR and platelet and total WBC counts were all significantly higher in atherogenic dietfed, saline-treated (Group II) rats than the mean values noted in control (Group I) rats (Fig. 1). However, the mean ESR and platelet and total WBC counts were significantly lower in atherogenic diet-fed, eugenoltreated (Group III) rats, when compared to the values in atherogenic diet-fed, saline-treated rats (Group II). These findings appear to corroborate the current concept that atherosclerosis is an inflammatory disease (Ross, 1999). In endothelial cells, the production of prostacyclin is decreased by aspirin, but despite the vasodilatory and platelet inhibitory effects of prostacyclin, platelet inhibition remains the prevailing effect of aspirin in patients with coronary artery disease (Grove, 2012).

Jia et al. (2005) reported that neutrophil, lymphocyte, and monocyte counts are predictive indicators of coronary artery disease. The independent association of neutrophil count with the angiographic characteristics of coronary atherosclerosis strongly suggests that granulocytosis may play a role in the development of coronary atherosclerosis (Jia et al., 2005). It is hypothesized that monocytes are recruited from the peripheral blood into the vessel wall after endothelial injury; the monocytes thus recruited differentiate into macrophages that phagocytose lipids and secrete metalloproteinase enzymes, such as elastase and collagenase, within the atherosclerotic lesion (Ross, 1999; Libby, 2001; Takahashi et al., 2002). In addition, neutrophils and mast cells, that secrete or induce degradative proteases, begin to accumulate in the plaque (Kaartinen et al., 1998; Laine et al., 1999; Naruko et al., 2002). In the present investigation, significantly higher mean percentages of neutrophils and monocytes and a lower mean percentage of lymphocytes were observed in blood samples from atherogenic diet-fed, saline-treated rats when compared to the values in blood samples from control rats (Table 2). However, atherogenic diet-fed, eugenol-treated rats exhibited lower mean percentages of neutrophils and monocytes and a higher mean percentage of lymphocytes in blood samples, when compared to the values in blood samples from atherogenic diet-fed, saline-treated rats (Table 2). Interestingly, no statistically significant difference was observed between the mean percentages of eosinophils in the blood samples from the three groups of rats. Although several studies have also reported similar findings in animal models of atherosclerosis (Getz and Reardon, 2012; Feig, 2014; Kapourchali et al., 2014), Kawaguchi et al. (1996) reported that the eosinophil count is virtually unrelated to coronary atherosclerosis in humans.

CRP, a marker of metabolic disturbances that increase the risk for the development of cardiovascular disease (Ross, 1999), is now considered to actively contribute to the progression of atherosclerosis. Genetic, metabolic, and other factors stimulate the expression of CRP in the liver and, possibly, also in the arterial wall. CRP binds to lipoproteins and damaged cells in atherosclerotic plaques, inducing complement activation and thus promoting inflammation and disease progression (Jan 2005). Serum levels of CRP are elevated in numerous disease states (Prasad, 2003). Elevated serum levels of CRP is an independent predictor of increased risk of atherosclerosis (Libby and Ridker, 2004), cardiovascular events (Black et al., 2004), atherothrombosis (Pepys and Hirschfield, 2001) hypertension (Sesso et al., 2003), and 
myocardial infarction (Ridker et al., 2002), even after considering the influence of other cardiovascular risk factors such as age, smoking, obesity, diabetes, hypercholesterolemia, and hypertension. In the present study, the mean serum level of CRP was significantly higher in atherogenic diet-fed, saline-treated rats than that noted in normal (control) rats (Table 3). Sun et al. (2005) reported that elevated levels of CRP have been noted in well-established animal models of atherosclerosis. Elevated mean levels of CRP were reported in an experimental model of atherosclerosis (Ramesh et al., 2010). Epidemiological studies have demonstrated a significant association between elevated serum/plasma CRP concentration and the prevalence of atherosclerotic vascular disease, the risk of recurrent cardiovascular events among those with established disease, or the incidence of first cardiovascular events among those at risk (Halim et al., 2012). These findings indicate the need for further investigation of human CRP concentration in cardiovascular disease (Ridker et al., 1997; 1998 and 2000) and acute coronary artery syndrome (Sivaraman et al., 2004). Interestingly in the present study, the mean serum level of CRP was significantly lower in atherogenic diet-fed, eugenol-treated rats than that in atherogenic diet-fed, saline-treated rats. In clinical studies, pravastatin (lipid-lowering drug) was found to reduce the plasma/serum levels of CRP in patients with dyslipidemia (Kent et al., 2003), coronary artery disease (Nissen et al., 2005), stable ischemic heart disease (Takeda et al., 2003), hypercholesterolemia with prior myocardial infarction (Ridker et al., 1999) and type 2 diabetes mellitus (Sommeijer et al., 2004).

In the present study, the mean hepatic tissue mRNA transcript level of the gene encoding CRP, as well as the mean hepatic tissue concentration of the CRP protein itself, were found to be significantly higher in atherogenic diet-fed, saline-treated (Group II) rats than the hepatic tissue values in control (normal, Group I) rats. However, in hepatic tissue samples from atherogenic diet-fed, eugenol-treated rats, the mean mRNA transcript level of the gene encoding CRP, and the mean concentration of the CRP protein itself, were significantly lower than the values in Group II rat hepatic tissue (Figs. 2 and 7), approaching nearnormal levels. These results suggest that treatment of atherogenic diet-fed rats with eugenol maintained expression of CRP at the transcriptional, as well as the translational, levels at near-normal intensity, thereby reducing the intensity of hypercholesterolemia-mediated inflammation.

Inflammation appears to play a central role in the occurrence of cardiovascular disease (Ridker et al., 1998; Hak et al., 1999 and Lagrand et al., 1999). Accordingly, several mediators of pro-inflammatory cytokines in endothelial cells, smooth muscle cells, monocytes, and cellular adhesion molecules have been evaluated as potential indicators of the risk of a first acute atherothrombotic event, as well as the initiation of atherosclerosis (Blake and Ridker, 2003). TNF-a is primarily produced by monocytes and macrophages. The possible involvement of TNF- $a$ in the pathogenesis of atherosclerosis is suggested by its presence in human atherosclerotic plaques (Kleemann et al., 2008). The secretion of TNF-a can be stimulated by oxidized LDL via activation of activator protein-1(AP-1) (Jovinge et al., 1996). Secreted TNF-a promotes cholesterol uptake and foam cell formation through NF-kB activation (Lei et al., 2009). Thus, TNF-a initiates positive feedback, leads to increased LDL uptake and consequent activation of TNFa release (Lei et al., 2009). In the present study, higher mean levels of mRNA transcripts of TNF-a were observed in hepatic tissue samples from atherogenic diet-fed, saline-treated rats than in those from 
normal rats (Fig. 5). Interestingly, treatment of atherogenic diet-fed rats with eugenol (Group III) appeared to maintain mRNA transcript levels of TNF-a in hepatic tissue at near-normal levels (Fig. 5).

In the early stages of atherosclerosis, hypercholesterolemia-mediated oxidative stress leads to the release of pro-inflammatory cytokines from infiltrating inflammatory cells (Evans et al., 2002). NF-kB, an important transcriptional factor, plays a vital role in the development and progression of cardiovascular diseases, such as atherosclerosis and acute coronary syndromes (Monaco and Paleolog, 2004). Among many transcriptional factors involved in oxidative stress-responsive intracellular signaling pathways, NF$\mathrm{KB}$ is known to be rapidly induced and is exquisitely sensitive to cellular oxidative status in hypercholesterolemia-mediated oxidative stress, leading to the release of pro-inflammatory cytokines from infiltrating inflammatory cells (Barnes and Karin, 1997). Upon its activation and translocation to the nucleus, NF-KB undergoes serine phosphorylation at residue 276 in its p65 subunit and associates with surrounding chromatin components. Therefore, measurement of the phosphorylated p65 subunit of NF$\mathrm{KB}$ is an effective tool for determining NF-KB activation (Okazaki et al., 2003). In the present study, the mean hepatic tissue mRNA transcript level of the gene encoding NF-kB, as well as the mean hepatic tissue concentration of the NF-kB protein itself, were found to be significantly higher in atherogenic dietfed, saline-treated rats than the hepatic tissue values in control (normal, Group I) rats. However, in hepatic tissue samples from atherogenic diet-fed, eugenol-treated rats, the mean mRNA transcript level of the gene encoding NF-kB, and the mean concentration of the NF-kB protein itself, were significantly lower than the values in Group II rat hepatic tissue (Figs. 4 and 7), and, approached near-normal levels. These findings suggest that oral administration of eugenol potentially inhibits the production of NF-kB-mediated pro-inflammatory cytokines, and thereby alleviates the systemic inflammatory response. These results are similar to those of Ewing et al. (2011), in which mice fed with a cholesterol-rich diet were treated with annexin A5 (a phospholipid-binding protein), resulting in reduced local vascular and systemic inflammation and vascular remodeling and improved vascular function, suggesting therapeutic potential against atherosclerotic cardiovascular diseases.

IL-1 $\beta$ is a pro-inflammatory cytokine that has been implicated in pain, inflammation, and autoimmune conditions (Ren and Torres, 2009). IL-1 $\beta$ is released primarily by monocytes and macrophages as well as by non-immune cells, such as fibroblasts and endothelial cells, during cellular injury, infection, invasion, and inflammation (Zhang and An, 2007). High levels of IL-1 $\beta$ are reported to be related to rupture-prone atherosclerotic lesions (Galea et al., 1996; Ozeren et al., 2003). IL-1 $\beta$ production can be stimulated by cholesterol crystals and modified LDL (Duewell et al., 2010; Rajamaki et al., 2010). Accordingly, the IL-1 $\beta$ level appears to be modified by cholesterol-lowering drugs, such as atorvastatin (Waehre et al., 2004; Ye et al., 2006 and Han et al., 2012). In the present study, higher mean levels of mRNA transcripts of IL-1 $\beta$ were observed in hepatic tissue samples from atherogenic diet-fed, saline-treated rats than in those from normal rats (Fig. 6). Interestingly, treatment of atherogenic diet-fed rats with eugenol (Group III) appeared to maintain the mean mRNA transcript level of IL-1 $\beta$ in hepatic tissue at near normal (Fig. 6).

The enzyme complex, IKB kinase, is an essential activator of the NF-KB-signaling pathway which is involved in propagating the cellular response to inflammation (Häcker and Karin, 2006). The IKB kinase 
enzyme complex is part of the upstream NF-KB signal transduction cascade. IKB-a, a protein that inhibits $\mathrm{kB}$, inactivates the NF-kB transcription factor by masking the nuclear localization signals of NF-kB proteins, therein keeping them sequestered in an inactive state in the cytoplasm (Mercurio et al., 1997; Xu et al., 2012; Ibrahim, 2014). IKB specifically phosphorylates the inhibitory IKB-a protein (Karin, 1999). This phosphorylation results in the dissociation of IKB-a from NF-KB. NF-KB, which is now free, migrates into the nucleus and activates the expression of at least 150 genes, some of which are anti-apoptotic (Karin, 1999). In addition, the proteasome inhibitors act by inhibiting the degradation of the inhibitor IKB-a, which occurs after IKB-a has been phosphorylated by the specific IKB-kinase as a result of activation of the early signal transduction pathway leading to NF-KB activation (Caterina and Manes, 2003). Similar studies have reported that IKB plays a key role in the expression of atherosclerosis by modulating macrophage functions involved in atherogenesis. These results suggest that inhibiting nuclear factor-kB activation in macrophages may represent a feasible approach to combat atherosclerosis (Park et al., 2012). In the present study, the mean level of ІкB protein in hepatic tissue was significantly higher in atherogenic dietfed, saline-treated rats than that in the hepatic tissue of control rats (Fig. 7). Interestingly, the mean hepatic tissue level of IKB protein was significantly lower in atherogenic diet-fed, eugenol-treated rats than that in atherogenic diet-fed, saline-treated rat hepatic tissue.

Inducible nitric oxide synthase (iNOS) is considered to be a mediator of increased oxidative stress and impaired vascular dysfunction (Gunnett et al., 2003). It has been hypothesized that iNOS contributes to the progression of atherosclerosis (Kuhlencordt et al., 2001). In particular, a large quantum of locallyreleased NO has been linked to the generation of harmful oxidative products, such as peroxynitrite and hydroxyl radicals; these have been implicated in iNOS-mediated development of atherosclerosis, (Tanaka et al., 1995; Wilcox et al., 1997; Saha and Pahan, 2006). iNOS expression is activated by NF-kB, which leads to inflammation and oxidative stress (Nathan, 1994).

The involvement of NO in chronic localized inflammatory diseases has been demonstrated in several experimental animal models. The occurrence of NO-mediated destruction of both rodent and murine islets of Langerhans and effects on insulin secretion, provide strong evidence for the involvement of NO in human diabetes (Kroncke et al., 1998). In addition, the presence of iNOS in atherosclerotic plaques also suggests a role for NO in atherosclerosis (Bult, 1996). Similar studies have shown a vasculoprotective role of iNOS against inflammatory cytokine-induced proliferative changes of the coronary artery in a porcine model of coronary arteriosclerosis (Fukumoto et al., 1997).

In the present study, the mean hepatic tissue level of mRNA transcripts of the gene encoding iNOS as well as the mean hepatic tissue level of the iNOS protein itself was found to be significantly higher in the atherogenic diet-fed, saline-treated rats than the mean levels in hepatic tissue of normal (control) rats (Fig. 3). Elevated hepatic tissue iNOS, noted at transcriptional and translational levels appeared to occur concomitantly with increased mean hepatic tissue levels of $\mathrm{NO}$ in atherogenic diet-fed, saline-treated rats in the current study (Table 4.4). However, in atherogenic diet-fed rats that had been treated with eugenol, such upregulation of mean hepatic tissue level of iNOS appears to have been prevented; moreover, the mean hepatic tissue NO level was not elevated. These observations in the current study suggest that 
eugenol treatment attenuated iNOS activation and subsequent production of NO, thereby preventing inflammation-mediated tissue damage and progression of atherosclerotic complications. Similarly, Wan et al. (2013) reported that berberine (an isoquinoline alkaloid used to treat diabetes) treatment blocked the production of noxious mediators (iNOS) involved in the development of atherosclerotic complications by attenuating the expression of iNOS at the transcript and translational levels with subsequent attenuated production of NO in hepatic tissue of rats.

\section{Conclusion}

The regulatory effect of eugenol on the expression of CRP, iNOS, and other inflammatory markers in a chronic experimental model of atherosclerosis was assessed in the present study. The mean ESR, and mean platelet and total WBC counts in blood samples from atherogenic diet-fed followed by saline treatment rats were higher than the values in blood samples from control (normal rats) and blood samples from atherogenic diet-fed followed by eugenol treatment rats. The mean mRNA transcript levels of genes encoding the inflammatory markers, CRP, iNOS, IL-1ß, TNF-a, and NF-KB, in hepatic tissue samples were found to be significantly lower in the atherogenic diet-fed followed by eugenol treatment rats than those in the atherogenic diet-fed followed by saline treatment rats hepatic tissue; in addition, the mean hepatic tissue concentrations of the inflammatory marker proteins themselves (CRP, iNOS, NF-KB, $\mathrm{IK}-\mathrm{KB}$ ) were also lower in the atherogenic diet-fed followed by eugenol treatment rats than the mean hepatic tissue concentrations of this protein in atherogenic diet-fed followed by saline treatment rats, as confirmed by Western blotting analysis. The observations made in the current set of experiments strongly suggest that eugenol possesses anti-inflammatory potential. These characteristics may play a vital role in eliciting a putative anti-atherogenic effect in Wistar rats fed an atherogenic diet.

\section{Declarations}

\section{Acknowledgments}

We thank professor Dr. P. Geraldine and Department of Animal Science, Bharathidasan University for providing lab facilities and support.

\section{Conflict of interests:}

The authors declare that there is no conflict of interests.

\section{Disclosure statement}

All the authors declare that there is no conflict of interest.

\section{Data availability statement}

The datasets used and analyzed during the current study are available from the corresponding author on reasonable request. 
Additional information

\section{Funding}

This work was supported by the Department of Animal Science, Bharathidasan University, Tiruchirappalli, Tamil Nadu, India.

\section{Ethics}

All experimental protocols were performed by the institutional guidelines and protocols approved by the Institutional Animal Ethical Committee BDU/IAEC/Tamil Nadu, India

\section{Authors Contribution}

A. Designed performed experiments, contributed to the writing of the final copy of the manuscript

B.C.D.F. They are corrected and revised in the Manuscript

E.G.H. They are updated and checked paper alignment as well as references session

\section{References}

1. Andresdottir, M.B., Sigfusson, N., Sigvaldason, H., Gudnason, V., 2003. Erythrocyte sedimentation rate, an independent predictor of coronary heart disease in men and women: The Reykjavik Study. Am J Epidemiol, 158(9), 844-851.

2. Barnes, P.J., Karin, M., 1997. Nuclear factor-kappaB: a pivotal transcription factor in chronic inflammatory diseases. N Engl J Med, 336 (15),1066-1071.

3. Biasucci, L.M., Liuzzo, G., Grillo, R.L., Caligiuri, G., Rebuzzi, A.G., et al., 1999. Elevated levels of Creactive protein at discharge in patients with unstable angina predict recurrent instability. Circulation, $99,855-860$.

4. Bjorkerud, S., Bjorkerud, B., 1996. Apoptosis is abundant in human atherosclerotic lesions, especially in inflammatory cells (macrophages and T cells), and may contribute to the accumulation of gruel and plaque instability. Am J Pathol, 149, 367-380.

5. Black, S., Kushner, I., Samols, D., 2004. C - reactive protein. J Biol Chem, 279 (47), 48487-90.

6. Blake, G.J., Ridker, P.M., 2003. C-reactive protein and other inflammatory risk markers in acute coronary syndromes. J Am Coll Cardio, 41, 37S-42S.

7. Bradford, M.M., 1976. A rapid and sensitive method for the quantitation of microgram quantities of protein utilizing the principle of protein-dye binding. Analytical Biochemistry, 72(1-2), 248-254.

8. Brigelius-Flohé, R., 2006. Glutathione peroxidases and redox-regulated transcription factors. Biol Chem, 387, 1329-1335. 
9. Bult, H., 1996. Nitric oxide and atherosclerosis: possible implications for therapy. Mol Med Today, 2, 510-518.

10. Castell, J.V., Gomez-Lechon, M.J., David, M., Fabra, R., Trullenque, R., Heinrich, P.C., 1990. Acute-phase response of human hepatocytes: regulation of acute-phase protein synthesis by interleukin- 6 . Hepatology, 12, 1179-86.

11. Caterina, R.D., Manes, C., 2003. Inflammation in early atherogenesis: impact of ACE inhibition. European Heart Journal Supplements, 5, A15-A24.

12. Colak, E., Majkic-Singh, N., Zoric, L., Radosavljevic, A., Kosanovic-Jakovic, N., 2012. The role of CRP and inflammation in the pathogenesis of age-related macular degeneration. Biochem Med (Zagreb), 22(1), 39-48.

13. Collins, T., Cybulsky, M.I., 2001. NF-kappaB: pivotal mediator or innocent bystander in atherogenesis. J Clin Invest, 107, 255-264.

14. Di Napoli, M., Schwaninger, M., Cappelli, R., Ceccarelli, E., Di Gianfilippo, G., et al., 2005. Evaluation of C-reactive protein measurement for assessing the risk and prognosis in ischemic stroke: a statement for health care professionals from the CRP Pooling Project members. Stroke, 36(6), 1316-29.

15. Duewell, P., Kono, H., Rayner, K.J., Sirois, C.M., Vladimer, G., et al., 2010. NLRP3 inflammasomes are required for atherogenesis and activated by cholesterol crystals. Nature, 464, 1357-1361.

16. Erikssen, G., Liestol, K., Bjornholt, J.V., Stormorken, H., Thaulow, E., Erikssen, J., 2000. Erythrocyte sedimentation rate: a possible marker of atherosclerosis and a strong predictor of coronary heart disease mortality. Eur Heart J, 21(19), 1614-1620.

17. Evans, J.L., Goldfine, I.D., Maddux, B.A., Grodsky, G.M., 2002. Oxidative stress and stress-activated signaling pathways: a unifying hypothesis of atherosclerosis. Endocr Rev, 23, 599-622.

18. Ewing, M.M., de Vries, M.R., Nordzell, M., Pettersson, K., de Boer, H.C., et al., 2011. Annexin A5 therapy attenuates vascular inflammation and remodeling and improves endothelial function in mice. Arterioscler Thromb Vasc Biol, (1), 95-101.

19. Feig, J.E., 2014. Regression of Atherosclerosis: Insights from Animal and Clinical Studies. Ann Glob Health, 80 (1), 13-23.

20. Fujisawa, S., Atsumi T., Kadoma, Y., et al., 2000. Radical generation, radical-scavenging activity, and cytotoxicity of eugenol compounds. Toxicol In Vitro, 13 (4), 269-79.

21. Fukumoto, Y., Shimokawa, H., Kozai, T., Kadokami, T., Kuwata, K., 1997. Vasculoprotective role of inducible nitric oxide synthase at inflammatory coronary lesions induced by chronic treatment with interleukin-1beta in pigs in vivo. Circulation, 96, 3104-3111.

22. Galea, J., Armstrong, J., Gadsdon, P., Holden, H., Francis, S.E., et al., 1996. Interleukin-1 $\beta$ in coronary arteries of patients with ischemic heart disease. Arterioscler Thromb Vasc Biol, 16, 1000-1006.

23. Getz, G.S., Reardon, C.A., 2012. Animal models of atherosclerosis. Arterioscler Thromb Vasc Biol, 32 , 1104-1115. 
24. Gilmour, D., Sykes, A.J., 1951. Westergren and Wintrobe Methods of Estimating E.S.R. Compared. Br Med J, 2 (4746), 1496-1497.

25. Gilmore, T.D., 2006. Introduction to NF-kappaB: players, pathways, perspectives. Oncogene, 25, 6680-6684.

26. Green, LC, Wagner, DA, Glogowski, J, Skipper, PL, Wishnok, JS, et al. Analysis of nitrate, nitrite, and [15N] nitrate in biological fluids. Anal Biochem, 1982; 126 (1): 131-8.

27. Grove, E.L., 2012. Antiplatelet effect of aspirin in patients with coronary artery disease. Dan Med J, 59 (9), B4506.

28. Gruenwald, T., Brendler, C., Jaenicke., 2004. PDR for Herbal Medicines, 3rd edition, Medical Economics Company, New Jersey, 245-246.

29. Gunnett, C.A., Heistad, D.D., Faraci, F.M., 2003. Gene-targeted mice reveal a critical role for inducible nitric oxide synthase in vascular dysfunction during diabetes. Stroke, 34(12), 2970-4.

30. Häcker, H., Karin, M., 2006. Regulation and function of IKK and IKK-related kinases. Sci STKE, 357, re13, 17047224. 10.1126/stke.3572006re13.

31. Hak, A., Stehouer, C., Bots, M., Polderman, et al., 1999. Associations of C-reactive protein with measures of obesity, insulin resistance, and subclinical atherosclerosis in healthy, middle-aged women. Arterioscler Thromb Vasc Biol, 19, 1986-1991.

32. Halim, S.A., Newby, L.K., Ohman, E.M., 2012. Biomarkers in cardiovascular clinical trials: past, present, future. Clinical Chemistry, 58 (1), 45-53.

33. Han, L., Li, M., Liu, Y., Han, C., Ye, P., 2012. Atorvastatin may delay cardiac aging by upregulating peroxisome proliferator-activated receptors in rats. Pharmacology, 89, 74-82.

34. Huang, Z.S., Jeng, J.S., Wang, C.H., Yip, P.K., Wu, T.H., et al., 2001. Correlations between peripheral differential leukocyte counts and carotid atherosclerosis in nonsmokers. Atherosclerosis, 158, 431436.

35. Ibrahim, N.L., 2014. TNF: A signaling pathway related to the activation of NF-KB. UK Journal of Pharmaceutical and Biosciences, 2 (3), 17-21.

36. Jan, N., 2005. CRP - Marker or Maker of Cardiovascular Disease? Arterioscler Thromb Vasc Biol, 25, 1527-1528.

37. Jia, E.Z., Yang, Z.J., Yuan, B., et al., 2005. Relationship between leukocyte count and angiographical characteristics of coronary atherosclerosis. Acta Pharmacol Sin, 26 (9), 1057-1062.

38. Jovinge, S., Ares, M.P., Kallin, B., Nilsson, J., 1996. Human monocytes/macrophages release TNFalpha in response to Ox-LDL. Arterioscler Thromb Vasc Biol, 16, 1573-1579.

39. Kaartinen, M., van der, Wal, A.C., van der Loos, C.M., et al., 1998. Mast cell infiltration in acute coronary syndromes: implications for plaque rupture. J Am Coll Cardiol, 32, 606-612.

40. Kapourchali, F.R., Surendiran, G., Chen, L., Uitz, E., Bahadori, B., et al., 2014. Animal models of atherosclerosis. World J Clin Cases, 2 (5), 126-132. 
41. Karin, M., 1999. How NF-kappa B is activated: the role of the I kappa-B kinase (IKK) complex. Oncogene, 18 (49), 6867-74.

42. Karin, M., Ben-Neriah, Y., 2000. Phosphorylation meets ubiquitination: the control of NF-[kappa] B activity. Annu Rev Immunol, 18, 621-663.

43. Kawaguchi, H., Mori, T., Kawano, T., Kono, S., Sasaki, J., et al., 1996. Band neutrophil count and the presence and severity of coronary atherosclerosis. Am Heart J, 132, 9-12.

44. Kent, S.M., Flaherty, P.J., Coyle, L.C., Markwood, T.T., Taylor, A.J., 2003. Effect of atorvastatin and pravastatin on serum C-reactive protein. Am Heart J, 145, E8.

45. Kleemann, R., Zadelaar, S., Kooistra, T., 2008. Cytokines and atherosclerosis: a comprehensive review of studies in mice. Cardiovascular Research, 79, 360-376.

46. Kroncke, K.D., Fehsel, K., Kolb-Bachofen, V., 1998. Inducible nitric oxide synthase in human diseases. Clin Exp Immunol, 113, 147-156.

47. Kuhlencordt, P.J., Chen, J., Han, F., Astern, J., Huang, P.L., 2001. Genetic deficiency of inducible nitric oxide synthase reduces atherosclerosis and lowers plasma lipid peroxides in apolipoprotein Eknockout mice. Circulation, 103 (25), 3099-104.

48. Lagrand, W., Visser, C., Hermens, W., et al., 1999. C-reactive protein as a cardiovascular risk factor. More than an epiphenomenon? Circulation, 100, 96-102.

49. Laine, P., Kaartinen, M., Penttila, A., Panula, P., Paavonen, T., et al., 1999. Association between myocardial infarction and the mast cells in the adventitia of the infarct-related coronary artery. Circulation, 99, 361-369.

50. Lei, L., Xiong, Y., Chen, J., Yang, J.B., Wang, Y., et al., 2009. TNF-a stimulates the ACAT1 expression in differentiating monocytes to promote the CE-laden cell formation. J Lipid Res, 50, 1057-1067.

51. Li, W.R., Tsubouchi, S., Qiao, M., Haneda, K., Murakami, M., et al., 2006. Inhibitory action of eugenol compounds on the production of nitric oxide in RAW264.7 macrophages. Biomed. Res, 27, 69-74.

52. Libby, P., 2001. What have we learned about the biology of atherosclerosis? The role of inflammation. Am J Cardiol, 88, 3-6.

53. Libby, P., Ridker, P.M., 2004. Inflammation and atherosclerosis: role of C-reactive protein in risk assessment. Am J Med, 116 (6), 9S - 16S.

54. Libby, P., 2012. Inflammation in atherosclerosis. Arterioscler Thromb Vasc Biol, 32, 2045-2051.

55. Libby, P., Okamoto, Y., Rocha, V.Z., Folco, E., 2010. Inflammation in atherosclerosis: transition from theory to practice. Circ J, 74 (2), 213-20.

56. Linton, M.F., Fazio, S., 2003.Macrophages, inflammation, and atherosclerosis. Int J Obes Relat Metab Disord, 27 (3), S35-S40.

57. Mehta, J.L., Sukhija, R., Romeo, F., Sepulveda, J.L., 2007. Value of CRP in coronary risk determination. Indian Heart J, 59. 173-7.

58. Mercurio, F., Zhu, H., Murray, B.W., 1997. Shevchenko, A, Bennett, BL, et al. IKK-1 and IKK-2: cytokineactivated I Kappa-B kinases essential for NF-kappa B activation. Science, 278 (5339), 860-6. 
59. Monaco, C., Paleolog, E., 2004. Nuclear factor-kappa B: a potential therapeutic target in atherosclerosis and thrombosis. Cardiovasc Res, 61, 671-82.

60. Nathan, C., 1994. Nitric oxide and biopterin: a study in Chiaroscuro. J Clin Invest, 93 (5), 875-6.

61. Naruko, T., Ueda, M., Haze, K., et al., 2002. Neutrophil infiltration of culprit lesions in acute coronary syndromes. Circulation, 106, 2894-2900.

62. Nissen, S.E., Tuzcu, E.M., Schoenhagen, P., et al., 2005. Statin therapy, LDL cholesterol, C-reactive protein, and coronary artery disease. N Engl J Med, 352, 29-38.

63. Okazaki, T., Sakon, S., Sasazuki, T., Sakurai, H., Doi, T., et al., 2003. Phosphorylation of serine 276 is essential for p65 NF kappa B subunit-dependent cellular responses. Biochem Biophys Res Commun, 300 (4), 807-812.

64. Ou, H.C., Chou, F.I., Lin, T.M., et al., 2006. Protective effects of eugenol against oxidized LDL induced cytotoxicity and adhesion molecule expression in endothelial cells. Food Chem Toxicol, 44 (9), 1485-595.

65. Ozeren, A., Aydin, M., Tokac, M., Demircan, N., Unalacak, M., et al., 2003. Levels of serum IL-1b, IL-2, IL-8, and tumor necrosis factor-alpha in patients with unstable angina pectoris. Mediators Inflamm, $12,361-365$.

66. Parasakthy, K., Shanthi, S., Deepalokshmi, P., Niranjali, S.D., 1996. The antioxidant effect of eugenol and carbon tetrachloride-induced erythrocyte damage in rats. J Nutr Biochem, 7, 23-28.

67. Park, S.H, Sui, Y., Gizard, F., Xu, J., Pilier, J.R., et al., 2012. Myeloid-Specific ІкB Kinase $\beta$ deficiency decreases atherosclerosis in low-density lipoprotein receptor-deficient mice. Arterioscler Thromb Vasc Biol, 32, 2869-2876.

68. Pasceri, V., Willerson, J.T., Yeh, E.T., 2000. Direct proinflammatory effect of C-reactive protein on human endothelial cells. Circulation, 102, 2165-2168.

69. Pasceri, V., Cheng, J.S., Willerson, J.T., Yeh, E.T., 2001. Chang, J. Modulation of C-reactive proteinmediated monocyte chemoattractant protein-1 induction in human endothelial cells by antiatherosclerosis drugs. Circulation, 103, 2531-2534.

70. Pepys, M.B., Hirschfield, G.M., 2001. C-reactive protein and atherothrombosis. Ital Heart J, 2, 196-9.

71. Pepys, M.B., Hirschfield, G.M., 2003. C-reactive protein: a critical update. J Clin Invest, 111 (12), 1805-12.

72. Popa, C., Netea, M.G., van Riel, P.L., van der Meer, J.W., Stalenhoef, A.F., 2007. The role of TNF-a in chronic inflammatory conditions, intermediary metabolism, and cardiovascular risk. J Lipid Res, 48, 751-762.

73. Prasad, K., Kalra, J., 1993. Oxygen-free radicals and hypercholesterolemic atherosclerosis effect of vitamin E. Am Heart J, 125, 958-973.

74. Prasad, K., 2003. C-reactive protein and cardiovascular diseases. Int J Angiol, 12, 1-12.

75. Rajamaki, K., Lappalainen, J., Oo“rni, K., Va“lima“ki, E., Matikainen, S., et al., 2010. Cholesterol crystals activate the NLRP3 inflammasome in human macrophages: a novel link between cholesterol 
metabolism and inflammation. PLoS One, 5, 11765.

76. Ramesh, E., Geraldine, P., Thomas, P.A., 2010. Regulatory effect of epigallocatechin gallate on the expression of C-reactive protein and other inflammatory markers in an experimental model of atherosclerosis. Chemico-Biological Interactions, 183, 125-132.

77. Ren, K., Torres, R., 2009. Role of interleukin-1 $\beta$ during pain and inflammation. Brain Res Rev, 60 (1), 57-64.

78. Ridker, P.M., Rifai, N., Pfeffer, M.A., Sacks, F.M., Moye, L.A., et al., 1998. Inflammation, pravastatin, and the risk of coronary events after myocardial infarction in patients with average cholesterol levels. Cholesterol and Recurrent Events (CARE) Investigators. Circulation, 98, 839-844.

79. Ridker, P.M., Cushman, M., Stampfer, M.J., Tracy, R.P., Hennekens, C.H., 1997. Inflammation, aspirin, and the risk of cardiovascular disease in apparently healthy men. N Engl J Med, 337, 356-379

80. Ridker, P.M., Rifai, N., Pfeffer, M.A., Sacks, F.M., Moye, L.A., et al., 1998. Inflammation, pravastatin, and the risk of coronary events after myocardial infarction in patients with average cholesterol levels. Cholesterol and Recurrent Events (CARE) Investigators. Circulation, 98, 839-844.

81. Ridker, P.M., Rifai, N., Pfeffer, M.A., Sacks, F., Braunwald, E., 1999. Long-term effects of pravastatin on plasma concentration of C-reactive protein. The Cholesterol and Recurrent Events (CARE) Investigators. Circulation, 100, $230-5$.

82. Ridker, P.M., Hennekens, C.H., Buring, J.E., Rifai, N., 2000. C-reactive protein and other markers of inflammation in the prediction of cardiovascular disease in women. The New England Journal of Medicine, 342 (12), 836-843.

83. Ridker, P.M., Rifai, N., Rose, L., Buring, J.E., Cook, N.R., 2002. Comparison of C-reactive protein and low-density lipoprotein cholesterol levels in the prediction of first cardiovascular events. $\mathrm{N}$ Engl J Med, 347, 1557-65.

84. Ross, R., 1999. Atherosclerosis-an inflammatory disease. N Engl J Med, 340, 115-26.

85. Saha, R.N., Pahan, K., 2006. Signals for the induction of nitric oxide synthase in astrocytes. Neurochem Int, 49 (2), 154-63.

86. Sesso, H.D., Buring, J.E., Rifai, N., Blake, G.J., Gaziano, J.M., et al., 2003. C-reactive protein and the risk of developing hypertension. JAMA, 290, 2945-51.

87. Shashkin, P., Dragulev, B., Ley, K., 2005. Macrophage differentiation to foam cells. Curr Pharm Des, 11, 3061-3072.

88. Shrivastava, A.K., Singh, H.V., Raizada, A., Singh, S.K., 2015. C-reactive protein, inflammation, and coronary heart disease. The Egyptian Heart Journal, 67 (2), 89-97.

89. Silvestre-Roig, C., de Winther, M.P., Weber, C., Daemen, M.J., Lutgens, E., et al., 2014. Atherosclerotic plaque destabilization: mechanisms, models, and therapeutic strategies. Circ Res, 114 (1), $214-26$.

90. Sivaraman, S.K., Zachariah, G., Annamalai, P.T., 2004. Evaluation of C-reactive protein and other inflammatory markers in acute coronary syndromes. Kuwait Med J, 36, 35-37. 
91. Sommeijer, D.W., MacGillavry, M.R., Meijers, J.C., Van Zanten, A.P., Reitsma, P.H., et al., 2004. Antiinflammatory and anticoagulant effects of pravastatin in patients with type 2 diabetes, Diabetes Care, 27, 468-473.

92. Sun, H., Koike, T., Ichikawa, T., Hatakeyama, K., Shiomi, M., et al., 2005. C-reactive protein in atherosclerotic lesions: its origin and pathophysiological significance. Am J Pathol, 167, 1139-48.

93. Tak, P.P, Firestein, G.S., 2001. NF-kappaB: a key role in inflammatory diseases. J Clin Invest, 107 (1), 7-11.

94. Takahashi, K., Takeya, M., Sakashita, N., 2002. Multifunctional roles of macrophages in the development and progression of atherosclerosis in humans and experimental animals. Med Electron Microsc, 35, 179-203.

95. Takeda, T., Hoshida, S., Nishino, M., Tanouchi, J., Otsu, K., et al., 2003. Relationship between effects of statins, aspirin, and angiotensin II modulators on high sensitive C-reactive protein levels. Atherosclerosis, 169, 155-158.

96. Tanaka, Y., Shimizu, H., Sato, N., Mori, M., Shimomura, Y., 1995.<backgroundcolor:\#CCCCFF;bvertical-align:super;></background-color:\#CCCCFF;bvertical-align:super;> Involvement of spontaneous nitric oxide production in the diabetogenic action of streptozotocin. Pharmacology, 50 (2), 69-73.

97. Thaulow, E., Erikssen, J., Sandvik, L., Stormorken, H., Cohn, P.F., 1991. Blood platelet count and function are related to total and cardiovascular death in apparently healthy men. Circulation, 84, 613-617.

98. Torzewski, J., Torzewski, M., Bowyer, D.E., Frohlich, M., Koenig, W., et al., 1998. C reactive protein frequently colocalizes with the terminal complement complex in the intima of early atherosclerotic lesions of human coronary arteries. Arterioscler Thromb Vasc Biol, 18, 1386-92.

99. Venkadeswaran, K., Thomas, P.A., Geraldine, P. An experimental evaluation of the anti-atherogenic potential of the plant, Piper betle, and its active constituent, eugenol, in rats fed an atherogenic diet. Biomedicine \& Pharmacotherapy, 2016; 80: 276-288.

100. Verma, S., Wang, C.H., Li, S.H., et al., 2002. A self-fulfilling prophecy: C-reactive protein attenuates nitric oxide production and inhibits angiogenesis. Circulation, 106, 913-919.

101. Verma, S., Szmitko, P.E., Ridker, P.M., 2005. C-reactive protein comes of age. Nat Clin Pract Cardiovasc Med, 2 (1), 29-36.

102. Waehre, T., Yndestad, A., Smith, C., Haug, T., Tunheim, S.H., et al., 2004. Increased expression of interleukin-1 in coronary artery disease with downregulatory effects of HMG-CoA reductase inhibitors. Circulation, 109, 1966-72.

103. Wan, X., Chen, X., Liu, L., Zhao, Y., Huang, W.J., Zhang, Q., et al., 2013. Berberine ameliorates chronic kidney injury caused by atherosclerotic renovascular disease through the suppression of the NFkappa B signaling pathway in rats. PLoS ONE, 8 (3), e59794.

104. Wilcox, J.N., Subramanian, R.R., Sundell, C.L., Tracey, W.R., Pollock, J.S., et al., 1997. Expression of multiple isoforms of nitric oxide synthase in normal and atherosclerotic vessels. Arterioscler Thromb 
Vasc Biol, 17 (11), 2479-88.

105. Xu, X., Woo, C.H., Steere, R.R., Lee, B.C., Huang, Y., Wu, J., et al., 2012. EVI1 acts as an inducible negative feedback regulator of NF-KB by inhibiting p65 acetylation. J Immunol, 188 (12), 63716380 .

106. Ye, P., Sheng, L., Zhang, C., Liu, Y., 2006. Atorvastatin attenuating down-regulation of peroxisome proliferator-activated receptor-gamma in preventing cardiac hypertrophy of rats in vitro and in vivo, $\mathrm{J}$ Pharm Sci, 9, 365-75.

107. Zhang, J.M., An, J., 2007. Cytokines, inflammation, and pain. Int Anesthesiol Clin Spring, 45 (2), 2737.

108. Zwaka, T.P., Hombach, V., Torzewski, J., 2001. C-reactive protein-mediated low-density lipoprotein uptake by macrophages: implications for atherosclerosis. Circulation, 103, 1194-7.

\section{Figures}

Erythrocyte Sedimentation Rate

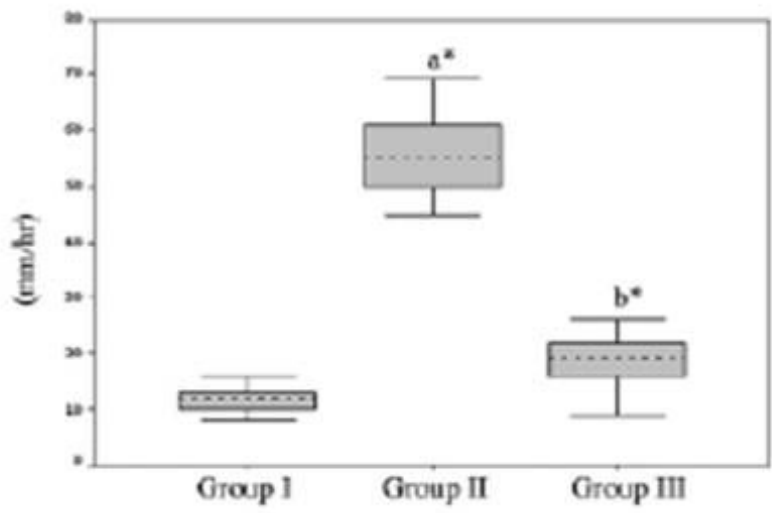

Platelet Count

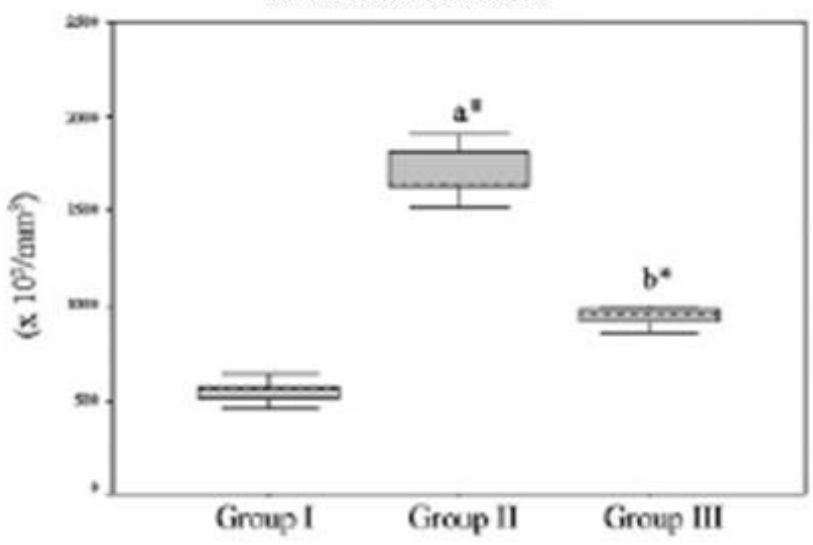

Total White Blood Cell Count

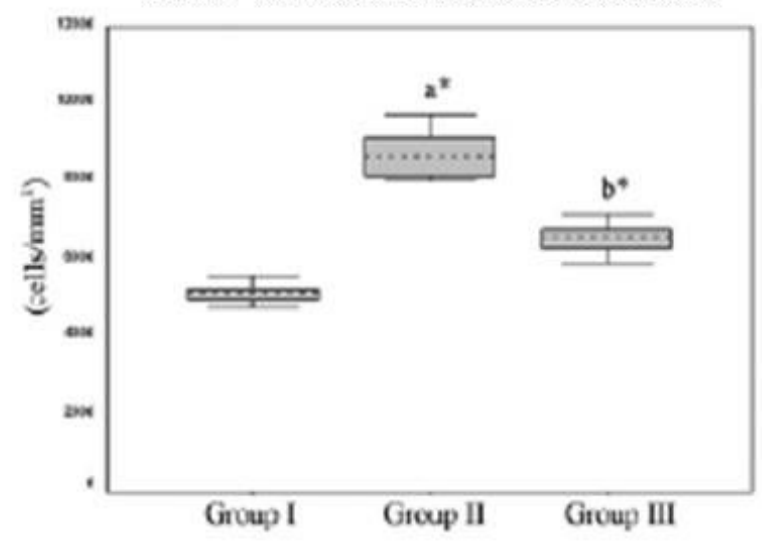

Figure 1 
Mean values of haematological parameters in blood samples from Wistar rats.

Statistical analysis: one-way analysis of variance [ANOVA] with post hoc testing [least significant difference]. Group I, normal; Group II, atherogenic diet-fed, saline-treated rats; Group III, atherogenic dietfed, eugenol-treated rats

aStatistically significant difference $(P<0.05)$ when compared with Group I values.

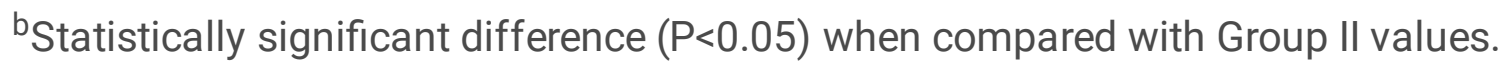

a)

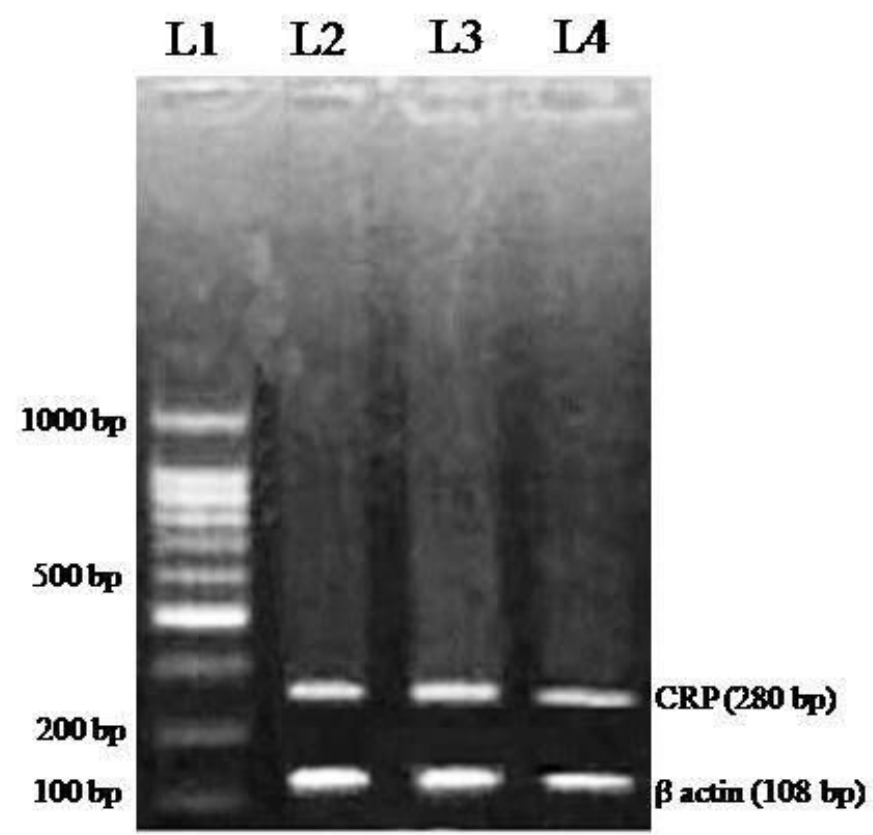

b)

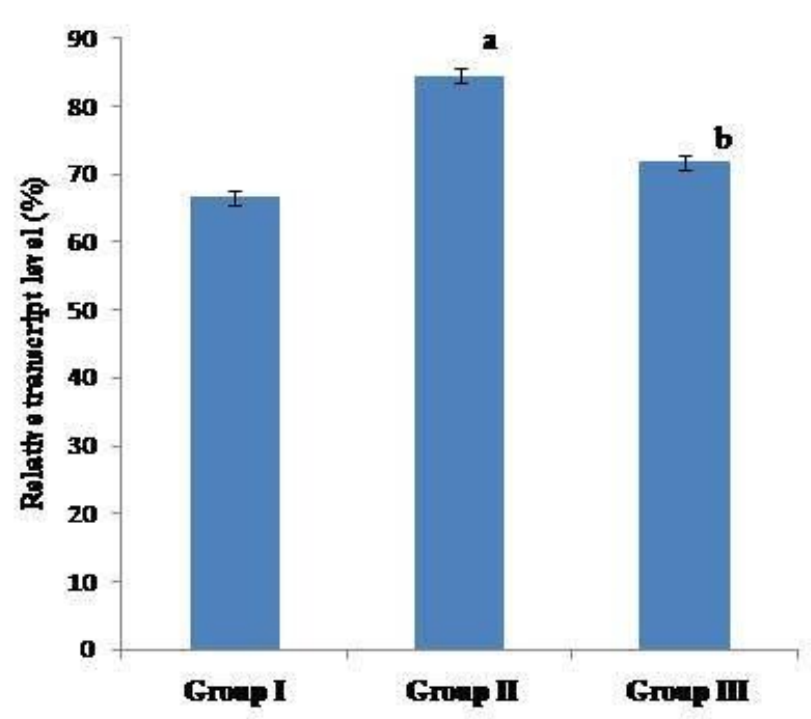

Figure 2

Differential expression of the gene encoding C-reactive protein in hepatic tissue samples from Wistar rats

(a) Reverse transcription-PCR (RT-PCR) analysis of C-reactive protein (CRP) gene expression in hepatic tissue samples visualized on an ethidium bromide-stained agarose gel with internal control gene $\beta$-actin;

(b) The mean hepatic tissue values (measured in triplicate) of mRNA transcript levels of CRP normalized to levels of control gene $\beta$-actin

Group I- control rats Group II- atherogenic diet-fed, saline-treated rats; Group III- atherogenic diet-fed, eugenol- treated rats. 
aStatistically significant difference $(P<0.05)$ when compared with Group I values.

bStatistically significant difference $(P<0.05)$ when compared with Group II values.

a)

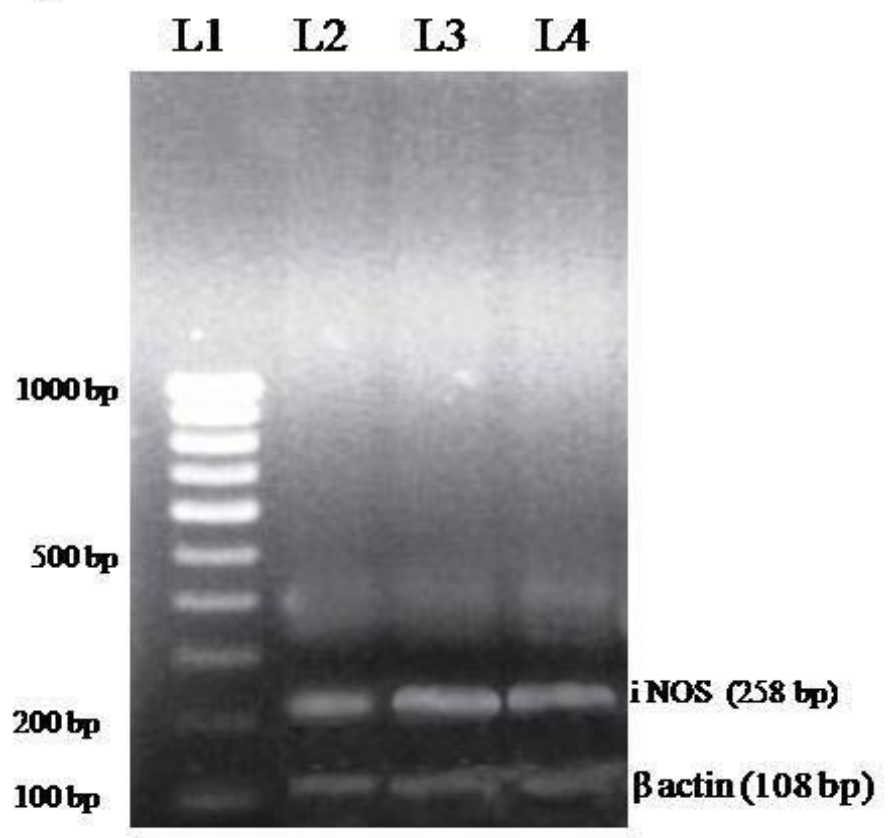

b)

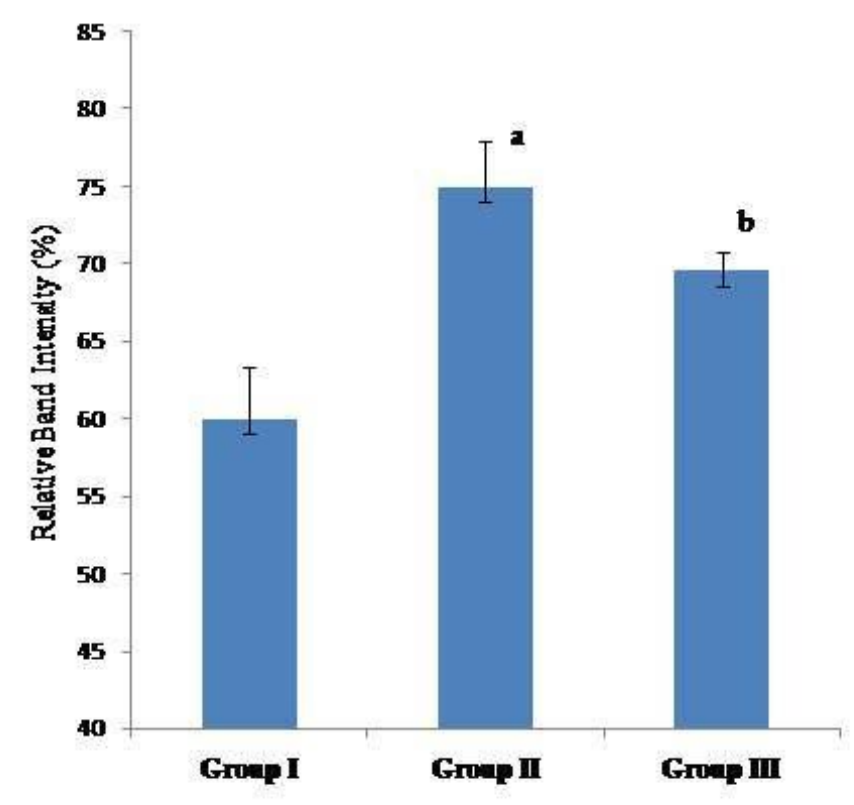

\section{Figure 3}

Differential expression of the gene encoding nitric oxide synthase in hepatic tissue samples from Wistar rats.

(a) Reverse transcription-PCR (RT-PCR) analysis of inducible nitric oxide synthase (iNOS) gene expression in hepatic tissue samples visualized on an ethidium bromide-stained agarose gel with internal control gene $\beta$-actin;

(b) The mean hepatic tissue values (measured in triplicate) of mRNA transcript levels of iNOS normalized to levels of control gene $\beta$-actin;

L1-100 bp DNA ladder; L2-control rats; L3-atherogenic diet-fed, saline-treated rats;

L4- atherogenic diet-fed, eugenol- treated rats.

Group I-control rats; Group II-atherogenic diet-fed, saline-treated rats; Group III- atherogenic diet-fed, eugenol- treated rats.

aStatistically significant difference $(P<0.05)$ when compared with Group I values. 
bStatistically significant difference $(P<0.05)$ when compared with Group II values.

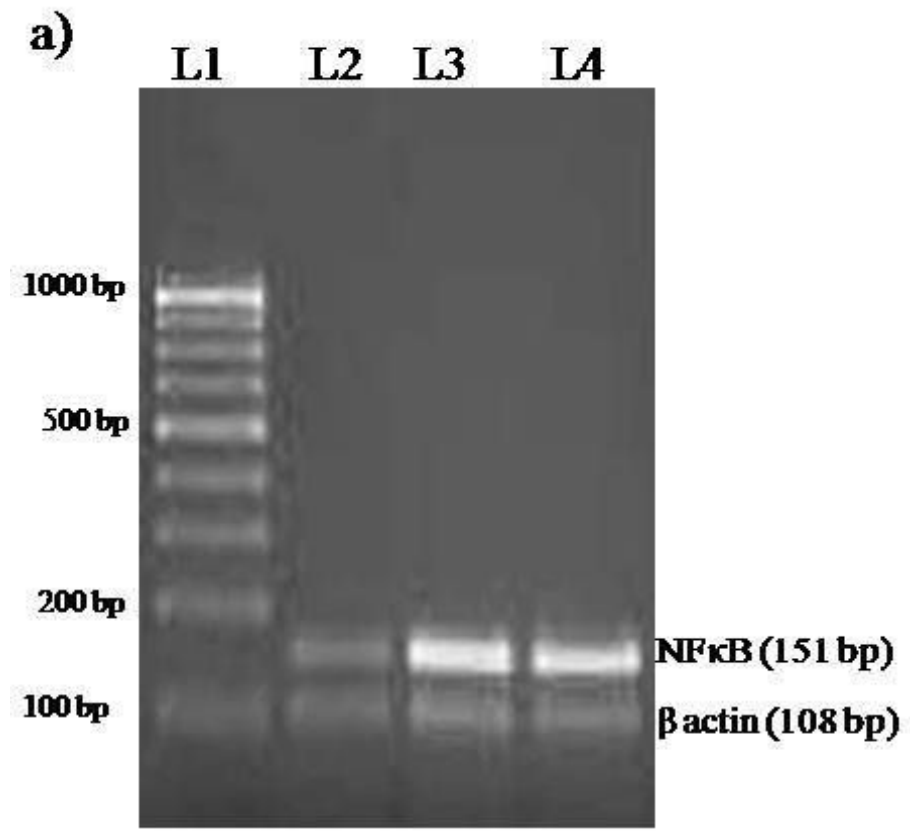

b)

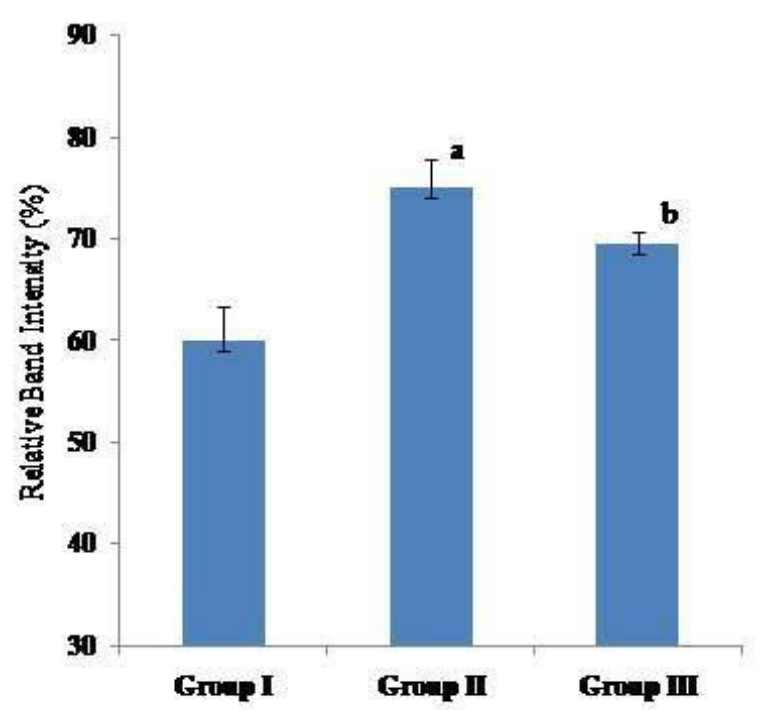

Figure 4

Differential expression of the gene encoding nuclear factor kappa B in hepatic tissue samples from Wistar rats

(a) Reverse transcription-PCR (RT-PCR) analysis of nuclear factor-KB (NF-KB) gene expression in hepatic tissue samples visualized on an ethidium bromide-stained agarose gel with internal control gene $\beta$-actin;

(b) The mean hepatic tissue values (measured in triplicate) of mRNA transcript levels of NF-kB normalized to levels of control gene $\beta$-actin;

L1-100 bp DNA ladder; L2-control rats; L3-atherogenic diet-fed, saline-treated rats;

L4- atherogenic diet-fed, eugenol- treated rats.

Group I-control rats; Group II-atherogenic diet-fed, saline-treated rats; Group III- atherogenic diet-fed, eugenol- treated rats.

aStatistically significant difference $(P<0.05)$ when compared with Group I values.

bStatistically significant difference $(P<0.05)$ when compared with Group II values. 
a)

b)
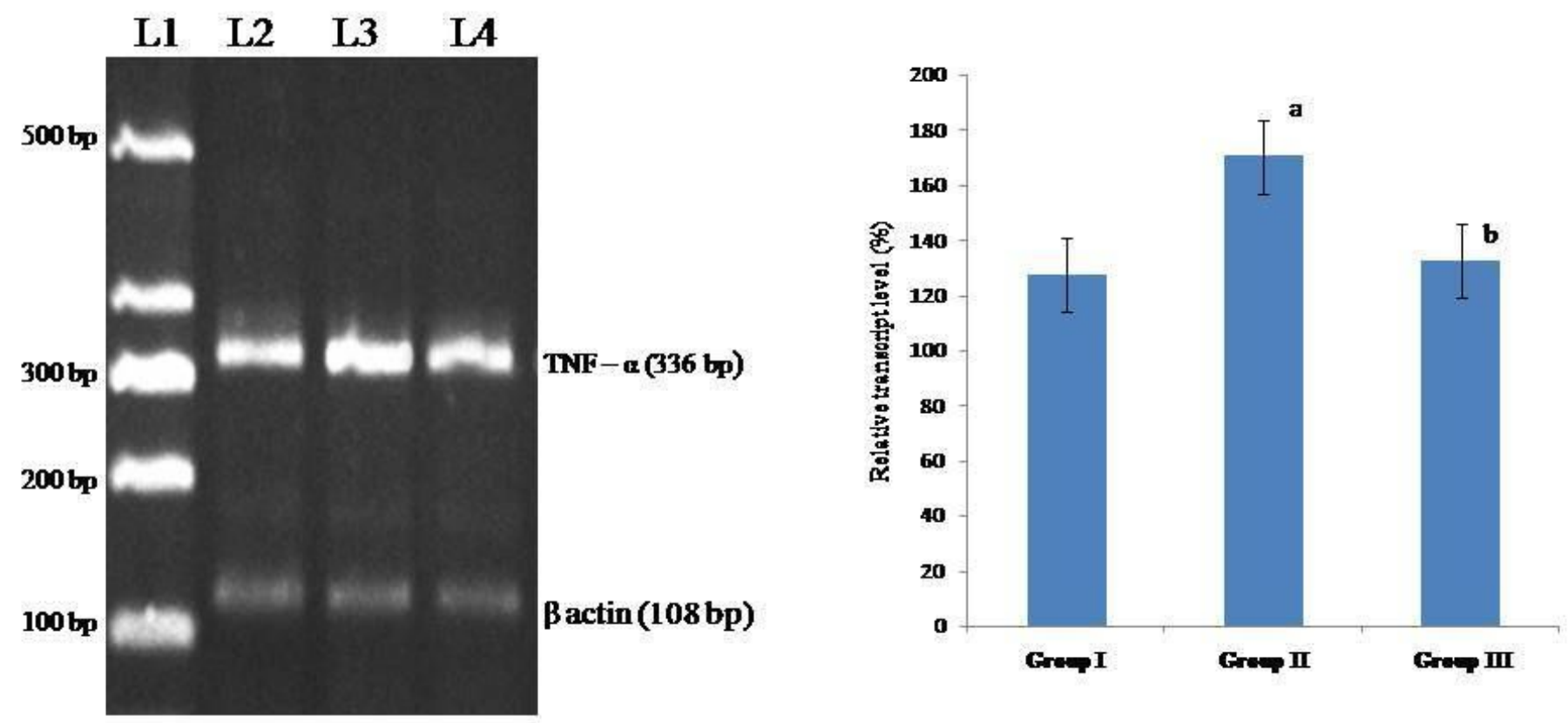

Figure 5

Differential expression of the gene encoding tumor necrosis factor alpha in hepatic tissue samples from Wistar rats

(a) Reverse transcription-PCR (RT-PCR) analysis of tumor necrosis factor- $a$ (TNF- $a$ ) gene expression in hepatic tissue samples visualized on an ethidium bromide-stained agarose gel along with internal control gene $\beta$-actin.

(b) Mean hepatic tissue values (measured in triplicate) of mRNA transcript level of TNF-a normalized to those of $\beta$-actin

L1-100 bp DNA ladder; L2-control rats; L3-atherogenic diet-fed, saline-treated rats; L4 - atherogenic dietfed, eugenol- treated rats.

Group I-control rats; Group II-atherogenic diet-fed, saline-treated rats; Group III- atherogenic diet-fed, eugnol- treated rats.

aStatistically significant difference $(P<0.05)$ when compared with Group I values.

bStatistically significant difference $(P<0.05)$ when compared with Group II values. 
a)

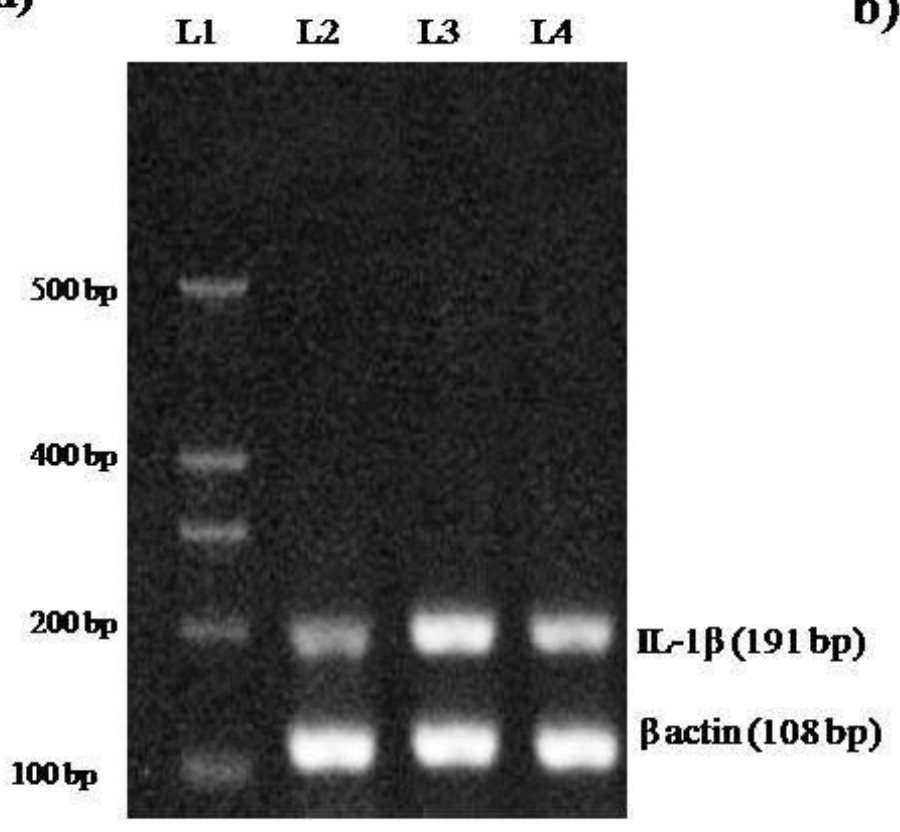

b)

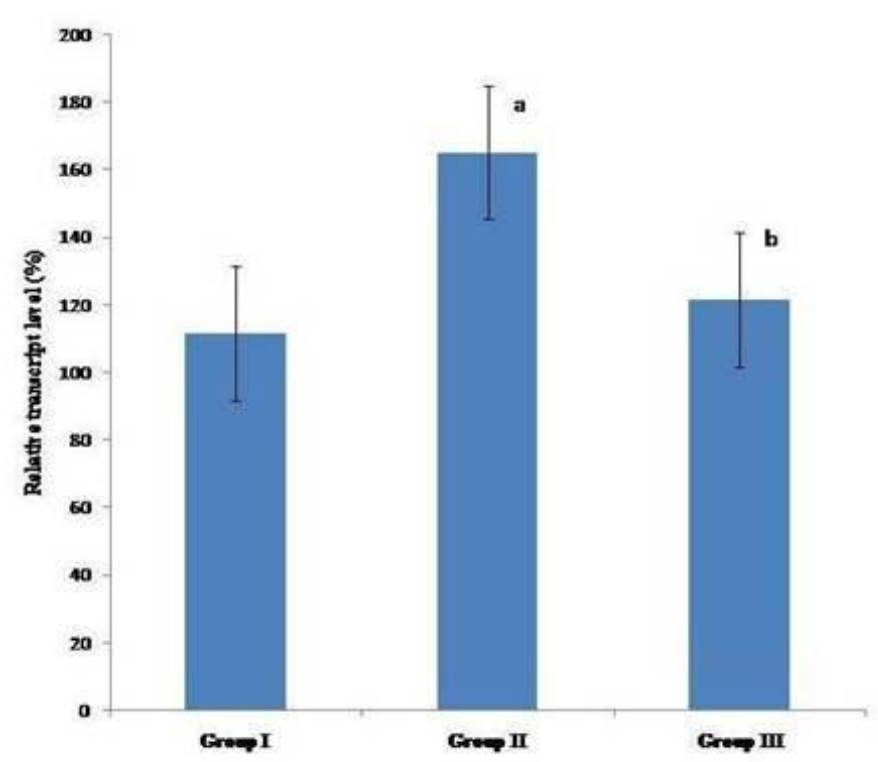

\section{Figure 6}

Differential expression of the gene encoding interleukin-1 $\beta$ in hepatic tissue samples from Wistar rats

(a) Reverse transcription-PCR (RT-PCR) analysis of interleukin-1 $\beta$ (IL-1 $\beta$ ) gene expression in hepatic tissue samples visualized on an ethidium bromide-stained agarose gel with internal control gene $\beta$-actin.

(b) Mean hepatic tissue values (measured in triplicate) of mRNA transcript levels of IL-1 $\beta$ normalized to those of $\beta$-actin.

L1-100 bp DNA ladder; L2-control rats; L3-atherogenic diet-fed, saline-treated rats; L4 - atherogenic dietfed, eugenol- treated rats.

Group I-control rats; Group II-atherogenic diet-fed, saline-treated rats; Group III- atherogenic diet-fed, eugenol- treated rats.

aStatistically significant difference $(P<0.05)$ when compared with Group I values.

bStatistically significant difference $(P<0.05)$ when compared with Group II values. 
a)

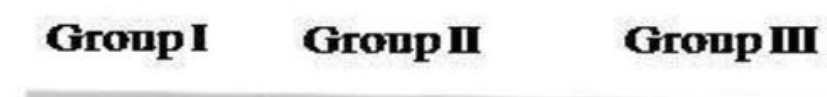

\section{CRP(118KDa)}

iNOS (130 KDa)

NFkB p65(90 KDa)

IxB ( 35 KDa)

B-actin ( 42 KDa)

b)

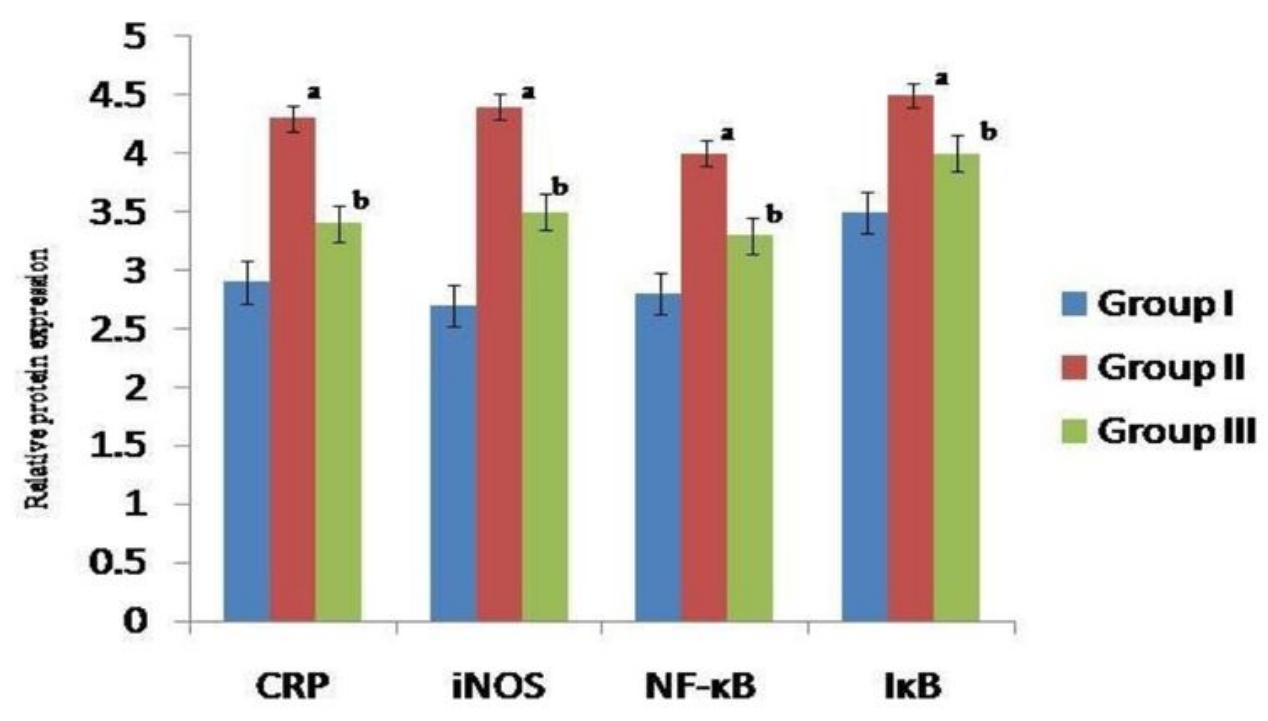

Figure 7

Mean levels of marker proteins of inflammation in hepatic tissue samples from Wistar rats

(a) Mean levels of C-reactive protein (CRP), inducible nitric oxide synthase (iNOS), nuclear factor-kB (NF$\mathrm{KB})$ and Inhibitory kinase proteins (IKB) in hepatic tissue samples from Wistar rats. 
(b) Bar graphs of mean normalized densitometry readings

Values represent the mean \pm SD of the band intensity (densitometric value) of each protein.

Statistical analysis: one way analysis of variance [ANOVA] with post hoc testing [least significant difference]. Group I, normal; Group II, atherogenic diet-fed, saline-treated rats; Group III, atherogenic dietfed eugenol-treated rats.

aStatistically significant difference $(P<0.05)$ when compared with Group I values.

bStatistically significant difference $(P<0.05)$ when compared with Group II values 